http://jurnal.unsil.ac.id/index.php/bioed/index

DOI: https://doi.org/10.34289/285227

\title{
PENGARUH MODEL PEMBELAJARAN SELF REGULATED LEARNING PADA KONSEP BIODIVERSITAS TERHADAP LITERASI SAINS DAN SIKAP ILMIAH SISWA KELAS X SMAN 5 KENDARI SULAWESI TENGGARA
}

\section{The Influence of Self Regulated Learning Model in Biodiversity Concept to Science Literacy and Scientific Attitude of X Grade Students of SMAN 5 Kendari, Southeast Sulawesi}

Rosman Sadat ${ }^{1)}$, Jahidin ${ }^{1)}$, Amirullah ${ }^{1)}$

${ }^{1)}$ Prodi Pendidikan IPA, Konsentrasi Pendidikan Biologi, Program Pascasarjana Universitas Haluoleo, Kampus Hijau Bumi Tridharma Anduonou Kendari, 93132

Email korespondensi: rosmansadat@gmail.com

\section{Info Artikel}

Sejarah Artikel: Diterima: 15 April 2019 Disetujui: 16 Mei 2019 Dipublikasikan: 30 Juni 2019

\section{Keywords:}

Self Regulated Learning Model, science literacy, scientific attitude

\begin{abstract}
Abstrak
Penelitian ini bertujuan untuk mendeskripsikan pengaruh Model Self Regulated Learning (SRL) dalam pada topik keanekaragaman hayati untuk (1) literasi sains (2) sikap ilmiah, dan (3) literasi sains dan sikap ilmiah siswa. SMAN 5 Kendari. Penelitian ini merupakan penelitian quasi dengan menggunakan desain kelompok kontrol nonequivalent pretest-posttest. Populasi penelitian adalah semua siswa kelas X MIA SMAN 5 Kendari pada semester ganjil tahun sekolah 2018/2019. Dua kelas sampel dipilih secara acak. Di satu sisi, model SRL digunakan di kelas eksperimen; di sisi lain, model instruksi langsung digunakan di kelas kontrol. Untuk teknik pengumpulan data, tes dan daftar inventaris digunakan. Tes ini digunakan untuk menentukan literasi sains dan daftar inventaris digunakan untuk menentukan sikap ilmiah siswa setelah berpartisipasi dalam model SRL dengan topik keanekaragaman hayati. Data dianalisis dengan menggunakan uji t sampel independen dan uji multivariat (MANOVA) dengan tingkat signifikansi 0,05. Hasil penelitian menunjukkan bahwa model SRL memiliki pengaruh yang signifikan pada (1) literasi sains, (2) sikap ilmiah, (3) literasi sains dan sikap ilmiah Siswa SMAN 5 Kendari. Kesimpulannya, model SRL memiliki efek signifikan pada literasi sains siswa dan sikap ilmiah.
\end{abstract}

\section{Abstract}

This study aims to describe the effect of Self Regulated Learning (SRL) Model in the Biology Subject on biodiversity topic to (1) the science literacy (2) the scientific attitude, and (3) the science literacy and the scientific attitude of the students SMAN 5 Kendari. This research was a quasy experiment using pretest-posttest nonequivalent control group designs. The study population was all students grade X MIA of SMAN 5 Kendari in the odd semester of the school year 2018/2019. Two sample classes were chosen randomly. On one side, the SRL model was used in the experimental class; on the other side, the direct instruction model was used in the control class. For the data collection techniques, test and inventory list were used. The test was used to determine the science literacy and the inventory list was used to determine scientific attitude of the students after participating in the SRL model with the topic of biodiversity. The data were analyzed using the independent sample t test and the multivariate (MANOVA) test with the significance level of 0,05. The results show that the SRL model has a significant effect on (1) the science literacy, (2) the scientific attitude, (3) the science literacy and scientific attitude of the Students of SMAN 5 Kendari. In conclusion, the SRL model has a significant effect on the students' science literacy and scientific attitude.

(C) 2019 Universitas Siliwangi

Alamat korespondensi:

Jurusan Pendidikan Biologi FKIP Universitas Siliwangi

Gedung Perkantoran FKIP Lt. 3

ISSN 2684-7604 (Online) ISSN 2477-5193 (Printed)

Jalan Siliwangi No. 24 Kota Tasikmalaya 46115

HP. 08112344989 (a.n. Rinaldi Rizal Putra, M.Sc.)

E-mail: bioedusiana@unsil.ac.id 


\section{PENDAHULUAN}

Abad ke-21 dan isu-isu yang menyertainya memunculkan permasalahan sekaligus tantangan baru bagi manusia dalam menjalani kehidupan (Asyhari, A, 2015). Dede (2015) menyatakan abad ke-21 diidentikan dengan arus globalisasi yang menegaskan bahwa dunia sedang berada pada abad semakin pesatnya pengetahuan, teknologi, informasi. Dampaknya mencangkup seluruh dimensi kehidupan manusia, yaitu pendidikan, ekonomi, komunikasi, dan budaya. Oleh karena itu, generasi Indonesia harus memiliki keterampilan dan kompetensi untuk menjadi pekerja efektif, masyarakat ilmiah dan moderen berbasis teknologi.

UNESCO World Conference on Education for All menjelaskan bahwa pendidikan sains harus memicu komunitas warga dunia yang berliterasi secara ilmiah dan teknologi, karena berpikir ilmiah adalah tuntutan setiap warga negara. Hal ini mendorong banyak negara untuk memberikan prioritas terhadap dimensi literasi sains dalam mengembangkan dan mengubah sains pada kurikulum sains (Arohman et al, 2016).

Literasi sains siswa indonesia masih sangat rendah (Thomson, 2013). Hal ini berdasarkan data PISA tahun 2012 (OECD, 2013), kemampuan literasi sains siswa Indonesia secara internasional masih sangat rendah yaitu berada pada peringkat 64 dari 65 negara peserta. Banyak faktor yang menyebabkan rendahnya literasi sains di Indonesia yaitu, gender, ekonomi dan sosial, serta imigrasi (Astuti, 2016). Kurang diperhatikannya lingkungan sosial budaya sebagai sumber pembelajaran juga menjadi penyebab rendahnya kemampuan literasi sains siswa di Indonesia (Nugraheni, 2017).

Self-Regulated Learning (SRL) adalah salah satu model pembelajaran yang mengacu pada kemampuan seseorang untuk memahami dan mengendalikan lingkungan belajarnya dan dapat membantu mengembangkan dan meningkatkan literasi sains dan sikap ilmiah siswa (Shuy, 2010). SRL menuntut siswa melakukan serangkaian aktivitas, kognitif, afektif, dan bahkan fisik yang jauh melampaui dari sekedar membaca dan mendengarkan saja (Hansen, 2015).

Literasi sains dan sikap ilmiah sebagai fokus dalam pembelajaran biologi pada materi keanekaragaman hayati melalui penerapan model SRL. Hal ini karena, guru Biologi di SMAN 5 Kendari belum mengarah ke arah pengembangan kemampuan literasi sains, sehingga penelitian mengenai pengaruh penerapan model SRL terhadap literasi sains dan sikap ilmiah siswa penting untuk dilakukan.

Tujuan penelitian ini yaitu untuk (1) mendeskripsikan pengaruh penerapan model pembelajaran SRL pada mata pelajaran Biologi materi keanekaragaman hayati terhadap kemampuan literasi sains siswa kelas X SMAN 5 Kendari, (2) mendeskripsikan pengaruh penerapan model pembelajaran SRL pada mata pelajaran Biologi materi keanekaragaman hayati terhadap kemampuan sikap ilmiah siswa kelas X SMAN 5 Kendari, (3) mendeskripsikan pengaruh penerapan model pembelajaran SRL pada mata pelajaran Biologi materi keanekaragaman hayati terhadap kemampuan literasi sains dan sikap ilmiah siswa kelas $\mathrm{X}$ SMAN 5 Kendari.

\section{METODE}

Penelitian ini merupakan penelitian eksperimen semu (quasi experiment) dengan desain pretest-posttest nonequivalen control group. Desain yang digunakan adalah rancangan analisis faktorial $2 \times 4$ yang melibatkan dua kelas yaitu kelas yang diajar melalui pendekatan saintifik dan kelas yang diajar dengan pembelajaran langsung (Creswell, 2014). Penelitian ini dilaksanakan di SMA Negeri Kabupaten Buton Selatan pada semester ganjil tahun ajaran 2018/2019 (SMA Negeri 5 Kendari).

Instrumen yang digunakan pada penelitian berupa tes essai untuk mengukur kemampuan literasi sains dan lembar inventori untuk penilaian sikap ilmiah (Gormally, 2012). Data penelitian ini akan dianalisis deskriptif, uji prasyarat dan inferensial. Analisis deskriptif 
digunakan untuk menyajikan data yang telah diperoleh dari hasil pretest dan posttest dan $n$ gain kemampuan literasi sains dalam kelompok eksperimen maupun kontrol. Uji prasyarat terdiri dari 2 yakni uji normalitas digunakan untuk mengetahui apakah data dari masingmasing variabel berdistribusi normal atau tidak. Pengujian ini dilakukan pada hasil n-gain atau peningkatan siswa masing-masing kelas. Uji homogenitas dilakukan untuk mengetahui apakah sampel penelitian berasal dari populasi yang homogen atau tidak. Pengujian ini dilakukan terhadap hasil n-gain atau peningkatan perolehan siswa masing-masing kelas. Analisis inferensial digunakan untuk uji independent sample $t$ dan uji multivariat (MANOVA). uji independent sample $t$ digunakan untuk menguji hipotesis 1 dan 2, sedangkan MANOVA digunakan untuk menguji hipotesis 3. Pada hipotesis 3 , penelitian ini menganalisis varians dengan variabel terikat yang lebih dari satu yang dianalisis secara bersamaan dan pengukurannya bersifat metrik. Dengan demikian, teknik analisisnya variannya menggunakan MANOVA (Hosnan, 2014).

\section{HASIL DAN PEMBAHASAN}

\section{A. Hasil Penelitian}

1. Analisis Deskriptif Literasi Sains dan Sikap Ilmiah

Grafik n-gain kemampuan berliterasi sains yang diperoleh menunjukkan bahwa peningkatan kemampuan literasi sains siswa kelas X MIA3 ada 10 siswa dengan kategori tinggi, 14 siswa dengan kategori sedang dan 1 siswa pada kategori rendah. Grafik n-gain kemampuan berliterasi sains yang diperoleh menunjukkan bahwa peningkatan kemampuan literasi sains siswa kelas X MIA 4 sebagian besar berada pada kategori sedang, 2 siswa dengan kategori gain tinggi, dan hanya satu orang siswa dengan kategori gain rendah.

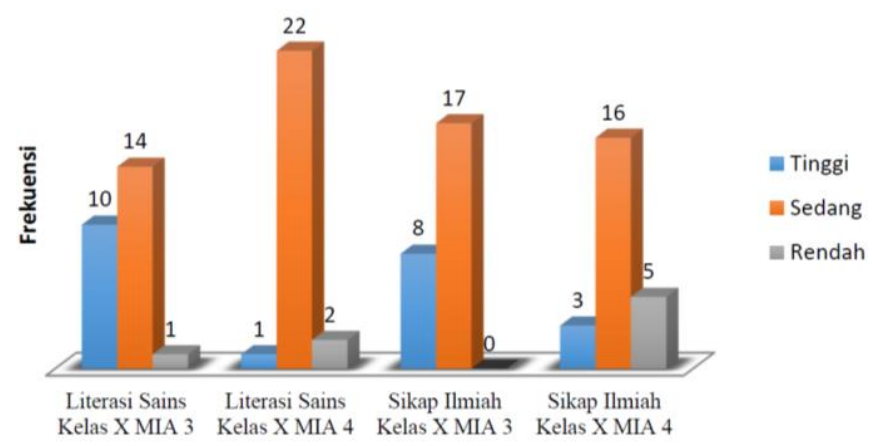

Gambar 1. Perbandingan Peningkatan Literasi Sains dan Sikap Ilmiah Kelas Eksperimen dan Kelas Kontrol

Grafik n-gain sikap ilmiah yang diperoleh menunjukkan bahwa peningkatan sikap ilmiah siswa kelas X MIA 3 sebagian besar berada pada kategori sedang dan tidak ada siswa pada kategori rendah. Grafik n-gain sikap ilmiah yang diperoleh menunjukkan bahwa peningkatan sikap ilmiah siswa kelas $\mathrm{X}$ MIA 4 sebagian besar berada pada kategori sedang yaitu ada 16 siswa, tiga siswa dengan kategori tinggi, dan 5 siswa pada kategori rendah. Grafik n-gain literasi sains dan sikap ilmiah kelas X MIA 3 dan X MIA 4 dapat dilihat pada Gambar 1.

\section{Analisis Uji Prasyarat}

\subsection{Uji Normalitas}

Data hasil uji normalitas, disajikan sebagaimana yang terdapat pada Tabel 1. Hasil uji normalitas untuk n-gain kemampuan literasi sains diperoleh nilai Asymp. Sig. (2-tailed) = $0,640 \geq 0,05=\alpha$ maka $\mathrm{H}_{0}$ diterima, hal ini berarti bahwa data $N$-gain kemampuan literasi sains kelas MIA 3 berdistribusi normal. Hasil uji normalitas untuk n-gain sikap ilmiah diperoleh nilai Asymp. Sig. (2-tailed) $=0,685 \geq$ $0,05=\alpha$ maka $\mathrm{H}_{0}$ diterima, hal ini berarti bahwa data n-gain sikap ilmiah kelas MIA 4 berdistribusi normal. 
Tabel 1. Ringkasan Hasil Uji Normalitas dengan Kolmogorov-Smirnov Test

\begin{tabular}{ccccc}
\hline Jenis Data & N & Asymp. Sig. & Sign ( $\alpha)$ & Kesimpulan \\
\hline $\begin{array}{c}\text { Gain literasi } \\
\text { sains }\end{array}$ & 50 & 0.640 & 0.05 & $\begin{array}{c}\text { Berdistribusi } \\
\text { normal }\end{array}$ \\
$\begin{array}{c}\text { Gain sikap } \\
\text { ilmiah }\end{array}$ & 50 & 0.685 & 0.05 & $\begin{array}{c}\text { Berdistribusi } \\
\text { normal }\end{array}$ \\
\hline
\end{tabular}

Tabel 2. Ringkasan Hasil Uji Homogenitas Varians dengan Levene's Test of Equality of Error

\begin{tabular}{cccc}
\hline F & df1 & Df2 & Asymp. Sig. \\
\hline 0.994 & 3 & $4,147 \mathrm{E} 5$ & 0.394 \\
\hline
\end{tabular}

Tabel 3. Hasil Uji Hipotesis 1

\begin{tabular}{cccc}
\hline $\mathbf{t}$ & Derajat Bebas & Signifikansi & Perbedaan Rata-rata \\
\hline 3.707 & 48 & 0.001 & 0.152 \\
\hline
\end{tabular}

Tabel 4. Hasil Uji Hipotesis 2

\begin{tabular}{cccc}
\hline $\mathbf{T}$ & Derajat Bebas & Signifikansi & Perbedaan Rata-rata \\
\hline 2.942 & 48 & 0.005 & 0.135 \\
\hline
\end{tabular}

Tabel 5. Hasil Uji Hipotesis 3

\begin{tabular}{ccc}
\hline Statistik & Nilai & Signifikansi \\
\hline Wilks' Lambda & 0,653 & 0,000 \\
\hline
\end{tabular}

\subsection{Uji Homongenitas}

Data uji homogenitas, disajikan sebagaimana pada Tabel 2. Uji homogenitas hipotesis 1 dan 2 menggunakan uji Lavene. Uji homogenitas hipotesis 3 menggunakan uji box $M$. Hasil uji homogenitas data literasi sains menggunakan uji Levene's test diperoleh nilai Sig $=0,393 \geq 0,05=\alpha$ maka $\mathrm{H}_{0}$ diterima, berarti data literasi sains memiliki varian yang sama. Hasil uji homogenitas data sikap ilmiah menggunakan uji Levene's test diperoleh nilai Sig $=0,735 \geq 0,05=\alpha$ maka $\mathrm{H}_{0}$ diterima, berarti data n-gain sikap ilmiah memiliki varians homogen. Hasil uji homogenitas untuk $n$-gain literasi sains dan sikap ilmiah menggunakan uji box $\mathrm{M}$ diperoleh pada nilai sig. $=0,394 \geq 0,05=\alpha$ maka $\mathrm{H}_{0}$ diterima, berarti bahwa data n-gain literasi sains dan sikap ilmiah memiliki varians yang homogen.

\section{Analisis Inferensial}

Tahap selanjutnya yaitu pengujian hipotesis untuk melihat alternatif ditolak atau diterima. Berikut hasil uji yang telah dilakukan.
Hasil Uji Hipotesis Pengaruh Signifikan Penerapan Model SRL Pada Literasi Sains Pengujian hipotesis 1 dilakukan dengan uji independent sample $t$ dengan bantuan SPSS 16 . Hasil uji hipotesis dapat dilihat pada Tabel 3.

Hasil pengujian hipotesis 1 diperoleh bahwa Sig $=0.001<\alpha(0,05)$, yang berarti H0 ditolak dan menerima H1. Dengan diterimanya H1, maka dapat disimpulkan bahwa ada pengaruh yang signifikan penerapan model pembelajaran SRL terhadap literasi sains siswa kelas X SMAN 5 Kendari.

Hasil Uji Hipotesis Pengaruh Signifikan Penerapan Model SRL Pada Sikap Ilmiah Pengujian hipotesis 2 dilakukan dengan uji independent sample $t$ dengan bantuan SPSS 16 . Hasil uji hipotesis dapat dilihat pada Tabel 4.

Hasil pengujian hipotesis 2 diperoleh bahwa Sig $=0.005<\alpha(0,05)$, yang berarti H0 ditolak dan menerima H1. Dengan diterimanya H1, maka dapat disimpulkan bahwa ada pengaruh yang signifikan penerapan model pembelajaran SRL terhadap sikap ilmiah siswa kelas X SMAN 5 Kendari. 
Pengujian hipotesis 3 dilakukan dengan uji MANOVA. Hasil Uji hipotesis 3 dapat dilihat pada Tabel 5. Hasil pengujian hipotesis diperoleh bahwa Sig. $=0,001<\alpha(0,05)$, yang berarti H0 ditolak dan menerima H1. Dengan demikian, dapat disimpulkan bahwa ada pengaruh yang signifikan penerapan model pembelajaran SRL pada mata pelajaran Biologi terhadap literasi sains dan sikap ilmiah siswa kelas X SMA Negeri 5 Kendari.

\section{B. Pembahasan}

Tujuan penelitian ini adalah untuk mengetahui ada atau tidaknya pengaruh dari penerapan model pembelajaran SRL terhadap literasi sains, pengaruh penerapan model pembelajaran SRL terhadap sikap ilmiah siswa, dan pengaruh penerapan model pembelajaran SRL terhadap literasi sains dan sikap ilmiah siswayang dianalisis sekaligus pada pelajaran Biologi. Pengaruh penerapan model pembelajaran tersebut dikhususkan bagi siswa kelas X SMAN 5 Kendari semester ganjil yang mempelajari materi keanekaragaman hayati. Pengaruh penerapan model pembelajaran tersebut secara khusus dinilai melalui adanya Perbedaaan kemampuan literasi sains diperoleh melalui tes, sedangkan sikap ilmiah diperoleh dari lembar inventori (Anwar, 2009). Hasil tes dan lembar inventori tersebut kemudian dianalisis dengan menggunakan uji independent sample $t$ dan uji multivariat untuk dapat menghasilkan kesimpulan atau jawaban permasalahan yang diajukan dalam penelitian ini. Selain menggunakan analisis statistika, salah satu cara yang dapat digunakan untuk untuk menunjukkan adanya perbedaan proses pembelajaran Biologi yang dihasilkan melalui penerapan model pembelajaran yang berbeda adalah dengan mendeskripsikan secara rinci masing-masing keunggulan dan kendala yang dialami selama berlangsunganya proses pembelajaran.

\section{Proses Pelaksanaan Penelitian}

Sebelum proses penelitian dilaksanakan telah dibuat perangkat pembelajaran dan instrumen penelitian pada materi keanekaragaan hayati. Perangkat pembelajaran terdiri dari, Rencana Pelaksanaan Pembelajaran (RPP), dan Lembar Kerja Siswa
(LKS) (Lestari, I. L., Utami, B., \& Budhiretnani, D. A. 2015).

Pada pembelajaran eksperimen siswa dibentuk dalam kelompok. Pada saat pelaksanaan diskusi antar kelompok, untuk pertemuan pertama siswa, terkesan kurang mampu menyesuaikan. Pada pembelajaran SRL ini siswa diberikan beberapa masalah berupa pertanyaan yang harus dijawab oleh siswa. Masalah tersebut menuntut mereka untuk lebih aktif membaca referensi dan memahaminya sendiri ataupun dengan bantuan rekan kelompoknya. Pada pertemuan pertama ini, siswa cenderung mempertahankan gaya belajarnya pada saat mengikuti pembelajaran seperti biasanya yaitu menunggu penjelasan dari guru. Adapun jika penjelasan dari guru ada yang tidak mereka pahami, mereka tidak bertanya atau diam saja. Hal ini terlihat dari respon siswa terhadap pertanyaan dan tanggapan terkait permasalahan dalam LKS yang hanya berasal dari anggota kelompok tertentu saja. Untuk mengatasi permasalahan tersebut, pada pertemuan pertama, guru membatasi tanggapan dan respon dari masing-masing anggota kelompok secara terarah.

Pada pertemuan kedua, siswa di kelas eksperimen mulai terbiasa dengan pembelajaran SRL. Pada pertemuan kedua, kerja sama yang ditunjukkan siswa terhadap kelompoknya terlihat lebih baik. Siswa juga mulai menunjukkan persaingan untuk menjadi kelompok terbaik, terlihat dari banyak buku referensi yang siswa gunakan untuk kelompoknya dalam melakukan diskusi dengan guru. Untuk mendapatkan kejelasan, siswa mulai bertanya lebih aktif pada kelompok yang sedang melakukan presentasi di depan kelas dan juga bertanya pada guru.

Pada pertemuan ketiga dan keempat respon siswa jauh lebih baik bila dibandingkan dengan pertemuan pertama dan kedua. Siswa yang diajar dengan menggunakan model pembelajaran SRL lebih aktif dan antusias dalam kegiatan pembelajaran. Hal tersebut tampak dari bertambahnya siswa yang mampu menjawab pertanyaan pembuka (tahap orientasi) pada tiap pertemuan. Pertanyaan apersepsi yang diajukan merupakan materi 
untuk pertemuan yang akan dipelajari. Banyaknya siswa yang mampu menjawab pertanyaan apersepsi menandakan bahwa ada inisiatif siswa mempelajari materi sebelum diadakan pembelajaran. Pada pembelajaran kelas eksperimen, guru lebih berfungsi sebagai fasilitator dan mediator, sehingga untuk dapat menjawab pertanyaan yang telah disajikan, siswa harus aktif membaca atau belajar materi yang terkait dengan permasalahan dan harus dapat memahami apa yang sedang dibacanya. Untuk dapat memahami apa yang sedang dipelajari, siswa membutuhkan waktu yang lebih lama dari pembelajaran langsung. Oleh karena itu, pada pembelajaran SRL pada penelitian ini dilakukan dengan pembentukan kelompok yang dimaksudkan agar siswa dengan anggota kelompoknya saling membantu dalam memahami materi pembelajaran Biologi yang sedang dipelajari.

Untuk pembelajaran di kelas kontrol, siswa mengikuti pembelajaran seperti yang biasa dilaksanakan oleh guru. Pelaksanaan model pembelajaran langsung dilaksanakan pada kelas MIA 4. Pada pembelajaran kelas kontrol ini, siswa diberi materi yang sama dengan kelas eksperimen hanya saja pada pembelajaran ini guru lebih banyak berperan dalam menanamkan konsep Biologi pada siswa. Siswa mendengarkan penjelasan guru, kemudian penjelasan guru tersebut dicatat oleh siswa dalam buku catatan, dan siswa melakukan kegiatan sesuai dengan petunjuk guru. Hal ini ternyata berpengaruh terhadap kemampuan literasi sains dan sikap ilmiah siswa.

\section{Pengaruh Model Pembelajaran SRL} terhadap Literasi Sains Siswa

Klein (2002: 2) menyatakan bahwa belajar pada dasarnya merupakan suatu proses pengalaman. Pengalaman dari belajar mengakibatkan perubahan perilaku pada individu yang relatif permanen. Perubahan perilaku tidak dapat dijelaskan pada keadaan sementara individu, kematangannya dan respon dari bawaan sejak lahir. Pengalamanpengalaman yang didapat siswa selama diterapkan pembelajaran SRL, mampu melatih kemampuan berliterasi sains. Model pembelajaran SRL adalah proses multidimensi yang tidak saja melibatkan kognitif, akan tetapi juga melibatkan emosional, perilaku, dan komponen kontekstual yang terintegrasi. Pada model pembelajaran SRL, siswa diarahkan untuk terlibat aktif melakukan perencanaan, mengikuti perkembangan dan memantau proses belajarnya sehingga menciptakan kemandirian belajar siswa. Siswa dilatih tentang pengaturan diri atau meregulasi diri untuk menyadari akan potensi yang dimiliki dan menggunakannya dengan baik dalam proses pembelajaran maupun dikehidupan nyata. Hal ini tetntu saja mampu meningkatkan kemampuan literasi sain. Mengingat Literasi sains sendiri memiliki pengertian sebagai kemampuan siswa yang mampu menggunakan konsep pembelajaran ke dalam sistuasi dunia nyata.

Pengaruh model pembelajaran SRL terhadap literasi sains dapat dilihat pada analisis $n$-gain literasi sains yang menggunakan uji independent sample $t$. berdasarkan uji independent sample $t$, diperoleh nilai sig. $=0,001$. Artinya nilai tersebut lebih kecil dari nilai $\alpha$ yaitu 0,05. Hal ini menandakan bahwa ada pengaruh yang signifikan penerapan model pembelajaran SRL terhadap literasi sains siswa kelas X SMAN 5 Kendari.

\section{Pengaruh Model Pembelajaran SRL} terhadap Sikap Ilmiah Siswa

Sikap ilmiah menjadi salah satu sikap penting yang harus dimiliki siswa dalam pembelajaran Biologi. Sikap Ilmiah adalah yang sesuai dengan hakekat ilmu pengetahuan. Sebagai pendidik, guru harus menerapkan model pembelajaran yang mampu membangun dan meningkatkan sikap ilmiah, termasuk model Pembelajaran SRL. Pengaruh model pembelajaran SRL terhadap sikap ilmiah dapat dilihat ada analisis n-gain sikap ilmiah siswa yang menggunakan uji independent sample $t$. berdasarkan uji independent sample t, pengaruh model pembelajaran SRL terhadap sikap ilmiah, diperoleh nilai sig. $=0,005$. Artinya nilai tersebut lebih kecil dari nilai $\alpha$ yaitu 0,05 . Hal ini menandakan bahwa ada pengaruh yang signifikan penerapan model pembelajaran SRL 
terhadap sikap ilmiah siswa kelas X SMAN 5 Kendari.

4. Pengaruh Model Pembelajaran SRL terhadap Literasi Sains dan Sikap Ilmiah Siswa

Pengaruh model pembelajaran SRL terhadap literasi sains dan sikap ilmiah dapat dilihat pada analisis n-gain literasi sains dan sikap ilmiah yang diuji menggunakan uji MANOVA. Hasil analisis diperoleh nilai Sig. = 0,000 . Artinya nilai tersebut lebih kecil dari nilai $\alpha$ yaitu 0,05 . Hal ini menandakan bahwa bahwa ada pengaruh yang signifikan penerapan model pembelajaran SRL pada mata pelajaran Biologi terhadap literasi sains dan sikap ilmiah siswa yang dianalisis secara sekaligus kelas $\mathrm{X}$ SMA Negeri 5 Kendari.

Berdasarkan hasil temuan penelitian dapat diketahui bahwa model pembelajaran SRL dapat melatih siswa belajar menyelesaikan permasalahan yang disajikan guru dalam LKS. Keterlibatan aktif sangat membantu siswa untuk membangun pengetahuan dan pemahaman sendiri. Pengetahuan dan pemahaman siswa dibangun melalui pemecahan masalah. Fokus kegiatan belajar sepenuhnya berada pada siswa yaitu berpikir menemukan solusi dari suatu masalah Biologi pada materi keanekaragaman hayati (Adholpus, et al, 2012).

Hal yang berbeda terjadi pada kelas kontrol. Pada pembelajaran kelas kontrol siswa selalu difasilitasi dan diarahkan, serta LKS yang diberikan seperti sebuah resep sehingga siswa dapat dengan mudah melakukan kegiatan pembelajaran dengan mengikuti tuntunan yang ada dalam LKS. Pada pembelajaran ini, guru yang berperan dalam menyajikan konsep-konsep kepada siswa, sehingga siswa tidak dilatih untuk mengkonstruksi pengetahuannya sendiri. Proses belajar yang terjadi adalah proses pemindahan informasi dari guru kepada siswa, bukan siswa yang menemukan apa yang dipelajari dan bukan siswa yang membangun pengetahuannya sendiri (Ulfa, S. W, 2016). SRL Memberikan siswa pengalaman belajar siswa dengan belajar bagaimana menyelesaikan masalah dan merefleksi apa yang telah dicapainya setelah melakukan pembelajaran .

Berdasarkan hasil penelitian dapat disimpulkan bahwa penerapan model pembelajaran SRL memiliki pengaruh yang signifikan dalam meningkatkan literasi sains siswa dan sikap ilmiah. Hal ini menunjukkan bahwa penerapan model pembelajaran SRL sejalan dengan teori-teori yang sebelumnya dikemukakan, yakni model pembelajaran SRL memiliki banyak keunggulan bila diterapkan dalam proses pembelajaran termasuk pengaruhnya yang positif terhadap litersai sains dan sikap ilmiah siswa (Patrianingsih, dkk 2016).

\section{SIMPULAN, SARAN, DAN REKOMENDASI}

Berdasarkan hasil penelitian dan pembahasan dapat disimpulkan :

1. Ada pengaruh yang signifikan penerapan model pembelajaran SRL pada mata pelajaran Biologi materi keanekaragaman hayati terhadap literasi sains siswa kelas $\mathrm{X}$ SMAN 5 Kendari

2. Ada pengaruh yang signifikan penerapan model pembelajaran SRL pada mata pelajaran Biologi materi keanekaragaman hayati terhadap ilmiah siswa kelas $\mathrm{X}$ SMAN 5 Kendari

3. Ada pengaruh yang signifikan penerapan model pembelajaran SRL pada mata pelajaran Biologi materi keanekaragaman hayati terhadap literasi sains dan sikap ilmiah siswa kelas X SMAN 5 Kendari.

\section{DAFTAR PUSTAKA}

Adholpus, Telima, \& Arokoyu, A. A. (2012). Improving Scientific Literacy among Secondary school students through integration of information and communication technology. ARPN Journal of Science and Technology , 2 (5), 444-448.

Anwar, H. (2009). Penilaian sikap ilmiah dalam pembelajaran sains. Jurnal Pelangi Ilmu , 103-114. 
Arohman, M., Saefudin, \& Priyandoko, D. (2016). Kemampuan literasi sains siswa pada pembelajaran ekosistem. Seminar Nasional XIII (ss. 90-92). Surakarta: Pendidikan Biologi FKIP UNS.

Astuti, Y. K. (2016). Literasi sains dalam pembelajaran IPA. ejournal.unwir.ac.id , VII (3B), 67-72.

Asyhari, A., \& Hartati, R. (2015). Profil peningkatan kemampuan literasi sains siswa melalui pembelajaran saintifik. Jurnal Ilmiah Pendidikan Fisika AlBiRuNi, 179-191.

Campbell, N. A., Reece, J. B., Urry, L. A., Cain, M. L., Wasserman, S. A., \& Minorsky, P. V. (2010). Biologi. (D. T. Wulandari, Övers.) San Francisco: Pearson Benjamin Cummings.

Creswell, J. W. (2014). Research design: qualitative,quantitative, \& mixed methods approach (4 uppl.). London: SAGE.

Dede, R. K. (2015). Pengaruh Model Pembelajaran Kimia Berbasis Masalah Terhadap Kemampuan Berpikir Kritis dan Hasil Belajar Kognitif Siswa Kelas $\mathrm{X}$ SMA Negeri 1 Lawa Sulawesi Tenggara. Tesis. Yogyakarta: Progam Pascasarjana Universitas Negeri Yogyakarta.

Depdiknas. (2003). Departemen Pendidikan Nasional Standar Kompetensi Mata Pelajaran Biologi SMA \& MA. Jakarta: Pusat Kurikulum.

Gormally, C., Peggy, B., \& Mary, L. (2012). Developing a Test of Scientific Literacy Skills (TOLS): Measuring Undergraduates' Evaluation of Scientific Information and Arguments. CBE-Life Sciences Education , 364-377.

Hansen, J. A. (2015). Assessing scientific literacy as participation in civic practices. Sweden: Holmbergs, Malmö.

Hosnan. (2014). Pendekatan saintifik dan kontekstual dalam pembelajaran abad 21: . Bogor: Ghalia Indonesia.
Klein, S. B. (2002). Learning: Principles and applications (4 th ed.) New York, NY:McGraw-Hill.

Lestari, I. L., Utami, B., \& Budhiretnani, D. A. ( 2015). Meningkatkan Kemampuan Berpikir Kritis dan Sikap Ilmiah Siswa melalui Perpaduan Metode Inquiry dan Resiprocal Teaching pada Materi Sistem Ekskresi di Kelas XI IPA 5 SMA Negeri 7 Kediri Tahun Pelajaran 2014-2015. Seminar Nasional XII Pendidikan Biologi FKIP UNS (ss. 276-280). Surakarta: Pendidikan Biologi FKIP UNS.

Nugraheni, N. C. (2017). Kemampun literasi sains kelas X SMA Negeri mata pelajaran biologi berdasarkan topografi wilayah Gunungkidul. Jurnal Prodi Pendidikan Biologi , 6 (5), 261-271.

OECD. (2013). Draft science framework PISA 2015. www.oecd.org.

OECD. (2016). Indonesian's Country Note: Results from PISA 2015. www.oecd.org.

Patrianingsih, E. A., \& Kaseng, E. S. (2016). Model pembelajaran discovery learning, pemahaman konsep biologi dan sikap ilmiah peserta didik. Jurnal Penelitian Pendidikan INSANI , 19 (2), 74-86.

Shuy, T. (2010). Self-Regulated Learning. Teaching Excellence in Adult Literacy, 1-3.

Thomson, S., Hillman, K., \& De Bortoli, L. (2013). A teacher's guide to PISA scientific literacy. Victoria: ACER Press.

Ulfa, S. W. (2016). Pembelajaran berbasis praktikum: upaya mengembangkan sikap ilmiah siswa pada pemelajaran biologi. NIZHAMIYAH Jurnal Pendidikan Islam dan Teknologi Pendidikan , 65-75. 